\title{
Quantifying field-scale effects of elevated carbon dioxide concentration on crops
}

\author{
Eline Vanuytrecht ${ }^{1, *}$, Dirk Raes ${ }^{1}$, Patrick Willems ${ }^{2}$, Sam Geerts ${ }^{1}$ \\ ${ }^{1}$ Division of Soil and Water Management, Department of Earth and Environmental Sciences \\ ${ }^{2}$ Hydraulics Laboratory, Department of Civil Engineering, KU Leuven University, 3001 Heverlee, Belgium
}

\begin{abstract}
Climate change will affect crop growth and agricultural production worldwide. Crop production will be affected not only by modified rainfall patterns, increased air temperatures and changes in evaporative demand, but also elevated atmospheric $\mathrm{CO}_{2}$ concentrations $\left(\left[\mathrm{CO}_{2}\right]\right)$. This study used meta-analytic techniques to quantify field-scale effects of elevated $\left[\mathrm{CO}_{2}\right]$ (mainly 541 to $620 \mu \mathrm{mol} \mathrm{mol}{ }^{-1}$ ) on agricultural crops in free air $\mathrm{CO}_{2}$ enrichment (FACE) conditions. Overall, crops benefit from elevated $\left[\mathrm{CO}_{2}\right]$ by improving water productivity $(+23 \%$ for biomass production and $+27 \%$ for yield production), which is achieved through production increases in biomass $(+15 \%$ for aboveground biomass) and yield $(+16 \%)$, in combination with a decrease in seasonal evapotranspiration $(-5 \%)$. Increased root:shoot ratios $(+24 \%)$ indicate a more than proportional stimulation of belowground biomass production. Less critical, yet statistically significant are changes in canopy development rate and in phenology. Certain statistically significant differences existed between $\mathrm{C} 3$ and $\mathrm{C} 4$ crops, and between levels of environmental stress (nitrogen and water availability). Once the effect of elevated $\left[\mathrm{CO}_{2}\right]$ is well understood and quantified, crop modellers can investigate the interactions with other climatic factors, providing better estimates of potential impacts on food production.
\end{abstract}

KEY WORDS: $\mathrm{CO}_{2}$ - Climate change C Crop productivity - FACE - Field-scale effects · Meta-analysis

Resale or republication not permitted without written consent of the publisher

\section{INTRODUCTION}

A steady increase of the atmospheric $\mathrm{CO}_{2}$ concentration $\left(\left[\mathrm{CO}_{2}\right]\right)$ has been manifested since the industrial revolution and will continue in the coming decades. The Intergovernmental Panel on Climate Change (IPCC) expects a rise in the $\left[\mathrm{CO}_{2}\right]$ of $\sim 2 \mu \mathrm{mol}$ $\mathrm{mol}^{-1} \mathrm{yr}^{-1}$ for the next decade, which can bring the $\left[\mathrm{CO}_{2}\right]$ in 2100 near to $550 \mu \mathrm{mol} \mathrm{mol}{ }^{-1}$ if no mitigation strategies are applied (IPCC 2007). Since elevated $\left[\mathrm{CO}_{2}\right]$ stimulates plant growth (Drake et al. 1997, Kimball et al. 2002, Ainsworth \& Long 2005), it has the potential to contribute to crop productivity increases that will be required to feed an increasing global population. It is therefore essential to estimate the extent of this effect.
Two basic kinds of models are used to assess crop productivity: (1) mechanistic models, which incorporate detailed physiological processes, and (2) functional models, which simplify complex processes, focusing on macro-growth processes. Functional models are most suitable for providing information about yield production at field- or larger scales (Benbi \& Nieder 2003). To make predictions in line with climate change, not only do shifts in climatic conditions (e.g. rainfall pattern, air temperature and evaporative demand) need to be considered, but also certain calculations need to be adjusted to account for the effect of $\left[\mathrm{CO}_{2}\right]$ (Tubiello \& Ewert 2002). Parry et al. (2004) compared yield predictions for scenarios of climate change with and without effects of elevated $\left[\mathrm{CO}_{2}\right]$. While yields generally declined under 
future weather conditions without taking into account elevated $\left[\mathrm{CO}_{2}\right]$, considering $\left[\mathrm{CO}_{2}\right]$ led to more positive predictions of yield production and water use than when elevated $\left[\mathrm{CO}_{2}\right]$ was not considered (Parry et al. 2004). Tubiello \& Ewert (2002) give an overview of agricultural models that incorporate the $\mathrm{CO}_{2}$ effect. There is a danger that models that have been parameterized and validated against enclosure experiments overestimate the $\mathrm{CO}_{2}$ effect (Long et al. 2006), and such models therefore need re-evaluating.

A clear understanding of the effect of $\mathrm{CO}_{2}$ on key growth processes and crop production is necessary when adjusting models. Knowledge can be gained in individual experiments with $\mathrm{CO}_{2}$ enrichment, but a broader general understanding can be achieved through meta-study (Cooper \& Hedges 1994). Metaanalytic methods offer good prospects to quantitatively synthesize research results from independent experiments (Hedges \& Olkin 1985, Cooper \& Hedges 1994, Osenberg et al. 1999). They have been widely applied in ecological research and more specifically in the exploration of crop responses to environmental change (e.g. Curtis \& Wang 1998, Wand et al. 1999). In contrast with common reviews or meta-studies, meta-analyses allow estimation of confidence intervals (CIs) in addition to the quantification of means, and also facilitate exploration of underlying patterns of variation in the responses to environmental change (Curtis \& Wang 1998, Borenstein et al. 2009). Existing reviews and meta-analyses are valuable as a basis for understanding plant responses to elevated $\left[\mathrm{CO}_{2}\right]$. However, these studies often discuss specific physiological processes (e.g. photosynthesis) and do not summarize information on macro-structural processes from emergence to maturity on a field-scale (e.g. canopy and phenological development) that are essential for functional models (e.g. Long et al. 2006, Ainsworth \& Rogers 2007). Some meta-analyses consider only a single crop and are therefore unsuitable for multi-crop models (e.g. Ainsworth et al. 2002, Ainsworth 2008), whilst other studies lump together woody species, herbaceous plants or wild species with field crops and do not consider specific aspects of plants with agricultural importance (e.g. Ainsworth \& Long 2005). Various studies combine chamber and free air conditions in the analysis (e.g. Wang 2007, Ainsworth 2008) although it is now believed that crop responses in chamber studies overestimate realistic responses and confuse predictions by models that have been evaluated against these data (Long et al. 2006, Ainsworth et al. 2008a). A number of meta-studies do not offer a statistical summary (Drake et al. 1997, McLeod \& Long 1999, Kimball et al.
2002) and are thus less suitable for drawing quantitative conclusions. A further justification for a new meta-analysis is that scientific knowledge on global change is quickly evolving, and meta-analytic knowledge should be updated regularly. The present analysis includes among others recent free air $\mathrm{CO}_{2}$ enrichment (FACE) experiments on rice in China and Japan, and on barley in Europe. Both crops have been under-addressed in previous research in comparison with their significance as food crops worldwide (Leakey 2009).

To avoid possible effects of enclosures and rely on experiments mimicking natural conditions, only FACE experiments were selected for the present study. The FACE technique avoids the potential limitations of (semi-) closed systems by studying the influence of elevated $\left[\mathrm{CO}_{2}\right]$ on crop growth in the field without chamber enclosure. An experiment consists of several uncovered plots (8 to $30 \mathrm{~m}$ diameter) where $\mathrm{CO}_{2}$ is released in and above the crop surface (McLeod \& Long 1999). The $\mathrm{CO}_{2}$ release is automatically adjusted in accordance with the monitored $\left[\mathrm{CO}_{2}\right]$, wind direction and wind velocity at the site. Advantages often attributed to FACE experiments are the minimal perturbations to the natural environment that they impose, and their large-scale nature. Drawbacks are the relatively high operational costs, the isolation of the $\mathrm{CO}_{2}$ effect from other environmental changes, and possible sideeffects caused by blower systems. Control plots serve to compare growth responses to elevated $\left[\mathrm{CO}_{2}\right]$ with ambient conditions (McLeod \& Long 1999).

The present study offers a quantitative overview of the effect of elevated $\left[\mathrm{CO}_{2}\right]$ on key macro-scale growth processes, parameters and variables of agricultural crops as observed in FACE experiments, the understanding of which is essential for the adaptation of functional models for a broad range of crops. The objectives of this study are (1) to quantify a general effect for different variables involved in crop development and production, and (2) to discover differences between subgroups (according to $\left[\mathrm{CO}_{2}\right]$ level, crop photosynthetic type and environmental stresses) and the pattern of variation in the mean effect. The findings should offer a basis for crop modellers to adapt functional models in order to assess crop productivity at elevated $\left[\mathrm{CO}_{2}\right]$.

\section{MATERIALS \& METHODS}

\subsection{Database compilation}

Peer-reviewed publications of primary FACE research were collected via searches in the ISI Web of 
Science citation database (ISI, Thomson) and the ScienceDirect citation database (Elsevier BV). The literature survey included all published studies conducted on key agricultural crops that were available in November 2011, and that provide information on one or more response variables listed in Table 1. The crops were as follows: wheat Triticum aestivum L., barley Hordeum vulgare L., rice Oryza sativa L., soybean Glycine max (L.) Merr., potato Solanum tuberosum L., sugar beet Beta vulgaris L., cotton Gossypium hirsutum L., maize Zea mays L. and sorghum Sorghum bicolor (L.) Moench; and in addition 2 major pasture species: perennial ryegrass Lolium perenne L. and white clover Trifolium repens $\mathrm{L}$.

The search was intended to be comprehensive and yielded 53 papers (details and full references in the supplement at www.int-res.com/articles/suppl/c054 p035_supp.pdf) that presented relevant data, either in graphical or numerical format. Within an individual study, different crop species or cultivars, nutrient or water stress treatments, experimental years, or different $\left[\mathrm{CO}_{2}\right]$ were assumed to be independent, which is a prerequisite to apply meta-analytic techniques (Curtis \& Wang 1998). If successive observations of a response variable throughout the growth cycle were available, one average value was calculated for the canopy growth coefficient (CGC) (see Section 2.3), or only the final value was considered for biomass $(B)$ production and root:shoot ratio $(R: S)$ to accomplish the prerequisite of independence (Curtis \& Wang 1998). This resulted in 529 independent observations suitable for meta-analysis. Mean values of response variables at elevated $\left[\mathrm{CO}_{2}\right]$ and in reference conditions, along with standard deviations (SDs) and sample sizes if available, were recorded directly from tables or digitized from figures using the Engauge Digitizer software (Free Software Foundation). If blower control plots were used, data for these plots were considered representative for reference conditions. Responses were never scaled to the level of elevated $\left[\mathrm{CO}_{2}\right]$, but differences in responses according to elevated $\left[\mathrm{CO}_{2}\right]$ were considered by comparison of different $\left[\mathrm{CO}_{2}\right]$ level categories (i.e. heterogeneity tests; see below).

The records in the database were grouped by categorical variables to allow investigation of the pattern of variation in effect size among groups of studies (Curtis \& Wang 1998, Osenberg et al. 1999). The categorical variables considered were elevated $\left[\mathrm{CO}_{2}\right]$ level (continuous values were arbitrarily classified in discrete levels of $\leq 540,541-580,581-620$, $>620 \mu \mathrm{mol}$ $\mathrm{mol}^{-1}$ ), water stress (rainfed versus well-watered), nitrogen stress (sufficient nitrogen versus nitrogen deficiency), and crop photosynthetic type (C3 versus $\mathrm{C} 4)$. If categorization tests indicated a difference in response magnitude according to elevated $\left[\mathrm{CO}_{2}\right]$ level, the database was first subdivided before other sources of heterogeneity were investigated. Differences in elevated $\left[\mathrm{CO}_{2}\right]$ of $<40 \mu \mathrm{mol} \mathrm{mol}^{-1}$ were considered negligible as the variation in $\left[\mathrm{CO}_{2}\right]$ in the FACE systems is of the same magnitude. Water and nitrogen stresses can be key aspects in the expression of the response to elevated $\left[\mathrm{CO}_{2}\right]_{i}$ therefore, it was considered compulsory to stratify for this aspect (Korner 2003). If publications did not provide unambiguous information on water or nitrogen stress, these categories were interpreted subjectively. Comparison of categories according to crop photosynthetic type can reveal different responses of crop subgroups.

\subsection{Statistical meta-analysis}

Statistical analysis was performed with MetaWin software (Rosenberg et al. 2000), following the approach of Curtis \& Wang (1998). The choice for a metric to describe the $\mathrm{CO}_{2}$ effect was guided by the characteristics of each response variable (Osenberg et al. 1999). For response variables describing phenology (anthesis, $A$ and maturity, $M$, expressed in d), the raw mean difference between means in elevated and control conditions $(D=$ response at elevated $\left[\mathrm{CO}_{2}\right]$ - response at ambient $\left[\mathrm{CO}_{2}\right]$, in d), was judged the proper metric for analyses (Borenstein et al. 2009). Hence, negative values of $D$ represent an acceleration of phenological development, while positive values indicate a delay. For all other variables, the $\mathrm{CO}_{2}$ effect was estimated by means of a response ratio $\left(R=\right.$ response at elevated $\left[\mathrm{CO}_{2}\right] /$ response at ambient $\left[\mathrm{CO}_{2}\right]$, unitless). The natural $\log$ of $R$ was used to provide a normal distribution centred on the true mean value (Hedges et al. 1999). $R$ allows expression of the mean percentage change of effect size due to elevated $\left[\mathrm{CO}_{2}\right]$ as: $(R-1) \times 100$.

If sample variances or standard errors with sample size for all independent observations of a particular variable were available, a weighted parametric analysis for mixed-models was preferred. Prior to the analysis, normality was checked as a precondition for applying parametric tests. Mixed-models were considered to be most appropriate as true effect sizes can exhibit small variations due to differences inherent to each individual study (Hedges et al. 1999). In fact, proper estimation of the mixed-model variance as weighting factor (Hedges et al. 1999) was only possible for one variable, the CGC, which was deduced 
from primary data (see Section 2.3). For other variables, missing sample variances were common and prompted use of unweighted techniques for which the variance of the effect size was calculated as a 95\% CI by resampling (Adams et al. 1997, Gurevitch \& Hedges 1999). In contrast with a weighted approach, unweighted randomization tests allowed inclusion of all available studies and avoided possible violation of the normality assumption. They were expected to yield reliable results since the statistical precision (i.e. the number of replications) of the various field experiments was comparable. The number of iterations used for the resampling technique was 4999, following suggestions by Adams \& Anthony (1996) and Adams et al. (1997). Estimates of the effect size were considered significant if the $95 \%$ CI did not include zero (Curtis \& Wang 1998, Morgan et al. 2003).

To examine whether different categories respond differently to elevated $\left[\mathrm{CO}_{2}\right]$, the heterogeneity $(Q)$ of the effect sizes was checked. The $Q$ test statistic has an approximate $\chi^{2}$-distribution and tests the null hypothesis that all of the effect sizes are equal (Gurevitch \& Hedges 1999). The larger $Q$ is, the greater the heterogeneity. Total heterogeneity $\left(Q_{\mathrm{T}}\right)$ was partitioned in within $\left(Q_{\mathrm{w}}\right)$ and between $\left(Q_{\mathrm{b}}\right)$ categorical heterogeneity - analogously to the examination of variance in analysis of variance-and distinguishes $Q_{\mathrm{w}}$ and $Q_{\mathrm{b}}$, such that $Q_{\mathrm{T}}=Q_{\mathrm{w}}+Q_{\mathrm{b}}$. $Q_{\mathrm{b}}$ for each categorical variable was first evaluated across all data, then the dataset was partitioned according to levels of those categorical variables with significant $Q_{\mathrm{b}}$ and the first step was repeated (Hedges \& Olkin 1985, Curtis \& Wang 1998). The $Q$ statistic was tested against a $\chi^{2}$-distribution for weighted analyses (Hedges \& Olkin 1985) and with randomization tests for unweighted analyses (Adams et al. 1997). If the obtained value of $Q$ exceeded a $(1-\alpha)$ critical value, the null hypothesis of homogeneity was rejected. Differences between categorical variables were assumed significant if the $95 \%$ CI did not overlap (Curtis \& Wang 1998), but in cases where the $95 \%$ CI did overlap, comparisons between categories were considered in the discussion to indicate notable trends.

\subsection{Response variables}

The analysis focused on 10 key factors describing macro-scale processes (Table 1). The CGC refers to the canopy growth rate before maximum canopy cover is reached (Steduto et al. 2009). It is an alternative measure to express the time to maximum canopy cover and describes early crop development better than leaf area index (LAI) or maximum LAI, variables that are addressed in other meta-studies. If LAI was reported, it was converted to canopy cover (CC) via Eq. (1), which was elaborated by Hsiao et al. (2009) and assumed applicable for all crops:

$$
\mathrm{CC}=1.005 \times[1-\exp (-0.6 \times \mathrm{LAI})]^{1.2}
$$

CGC was calculated for each field observation of canopy cover or LAI before maximum canopy cover via Eqs. (2 \& 3) (Raes et al. 2009):

Table 1. Key response variables considered in the meta-analysis

\begin{tabular}{|c|c|c|}
\hline Symbol & Response variable & Definition \\
\hline \multicolumn{3}{|c|}{ Crop water relations } \\
\hline $\mathrm{ET}$ & Evapotranspiration & $\begin{array}{l}\text { Actual evapotranspiration at field level throughout total } \\
\text { growing cycle (mm) }\end{array}$ \\
\hline $\mathrm{WP}_{B-\mathrm{ET}}$ & Water productivity for biomass production & Ratio $B$ :ET $\left(\mathrm{kg} \mathrm{m}^{-2} \mathrm{~mm}^{-1}\right)$ \\
\hline $\mathrm{WP}_{Y \text {-ET }}$ & Water productivity for yield production & Ratio $Y$ :ET $\left(\mathrm{kg} \mathrm{m}^{-2} \mathrm{~mm}^{-1}\right)$ \\
\hline \multicolumn{3}{|c|}{ Biomass production and yield formation } \\
\hline$R: S$ & Root:shoot ratio & $\begin{array}{l}\text { Ratio of belowground biomass over aboveground biomass } \\
\text { at maturity }\end{array}$ \\
\hline$B$ & Biomass & Dry aboveground biomass produced at maturity $\left(\mathrm{kg} \mathrm{m}^{-2}\right)$ \\
\hline $\mathrm{HI}$ & Harvest index & Ratio $Y: B$ \\
\hline$Y$ & Yield & Yield produced at maturity $\left(\mathrm{kg} \mathrm{m}^{-2}\right)$ \\
\hline \multicolumn{3}{|c|}{ Crop development } \\
\hline CGC & Canopy growth coefficient & $\begin{array}{l}\text { Increase of green canopy ground cover during canopy } \\
\text { expansion }\left(\% \mathrm{~d}^{-1}\right)\end{array}$ \\
\hline$A$ & Crop anthesis & Time from sowing to start of flowering $(\mathrm{d})$ \\
\hline$M$ & Crop maturity & Time from sowing to start of physiological maturity (d) \\
\hline
\end{tabular}




$$
\begin{gathered}
\mathrm{CC}=\mathrm{CC}_{\mathrm{o}} \times \exp (t \times \mathrm{CGC}), \text { if } \mathrm{CC} \leq \mathrm{CC}_{\mathrm{x}} / 2 \\
\mathrm{CC}=\mathrm{CC}_{\mathrm{x}}-0.25 \times\left(\mathrm{CC}_{\mathrm{x}}{ }^{2} / \mathrm{CC}_{\mathrm{o}}\right) \times \exp (-t \times \mathrm{CGC}), \\
\text { if } \mathrm{CC}>\mathrm{CC}_{\mathrm{x}} / 2
\end{gathered}
$$

where $\mathrm{CC}$ is the canopy cover at time $t$ (fraction); $\mathrm{CC}_{\mathrm{o}}$ is the initial canopy size at $t=0$ (fraction), equal to soil surface covered by an individual seedling times the planting density; $\mathrm{CC}_{\mathrm{x}}$ is the maximum canopy cover under optimal conditions (fraction); CGC is the increase of fraction ground cover per day; and $t$ is time (d).

The average CGC was determined and used for analysis. SDs around the calculated mean value represented the variance over the course of the early season. The statistical precision of the original experiments was considered, since the number of replications was similar for all experiments.

For the variables $A, M$, actual evapotranspiration $(\mathrm{ET})$, biomass $(B)$ and yield production $(Y)$, original values given in the primary publications were analyzed. Water productivity $\left(\mathrm{WP}_{B \text {-ET }}\right.$ and $\left.\mathrm{WP}_{Y \text {-ET }}\right), R: S$ ratio, and harvest index (HI) were analyzed directly if publications provided original values, or calculated as the ratios of $B: E T, Y: E T$, belowground biomass: $B$, and $Y: B$, respectively. Given the different morphologies of tuber and root crops, $B$ and $\mathrm{WP}_{B \text {-ET }}$ for potato and sugar beet included belowground biomass. The term water productivity was preferred to water use efficiency to avoid confusion with engineering terminology often referring to the efficiency of application systems.

\section{RESULTS}

\subsection{Overall effect of elevated $\left[\mathrm{CO}_{2}\right]$}

Except for $A$ and $M$, the variable response is represented as the mean percentage change due to elevated $\left[\mathrm{CO}_{2}\right]\left(541\right.$ to $\left.620 \mu \mathrm{mol} \mathrm{mol}{ }^{-1}\right)$ with reference to ambient $\left[\mathrm{CO}_{2}\right]$ (Fig. 1). Averaged across all studies, crops reached maximum canopy earlier as CGC increased by $4 \%$. Most notable was the improvement in water productivity $\left(\mathrm{WP}_{B \text {-ET }}+23 \%\right.$ and $\mathrm{WP}_{Y \text {-ET }}$ $+27 \%)$ and the increase in $R: S$ ratio $(R: S+24 \%)$. Aboveground biomass increased substantially (+15\%) and the effect on yield stimulation $(+16 \%)$ was similar. HI did not change significantly. Crop ET decreased by $5 \%$. All effect sizes are summarized in Table S2 in the Supplement at www.int-res.com/ articles/suppl/c054p035_supp.pdf.

The effect of elevated $\left[\mathrm{CO}_{2}\right]$ on phenological development is represented as the mean difference in days

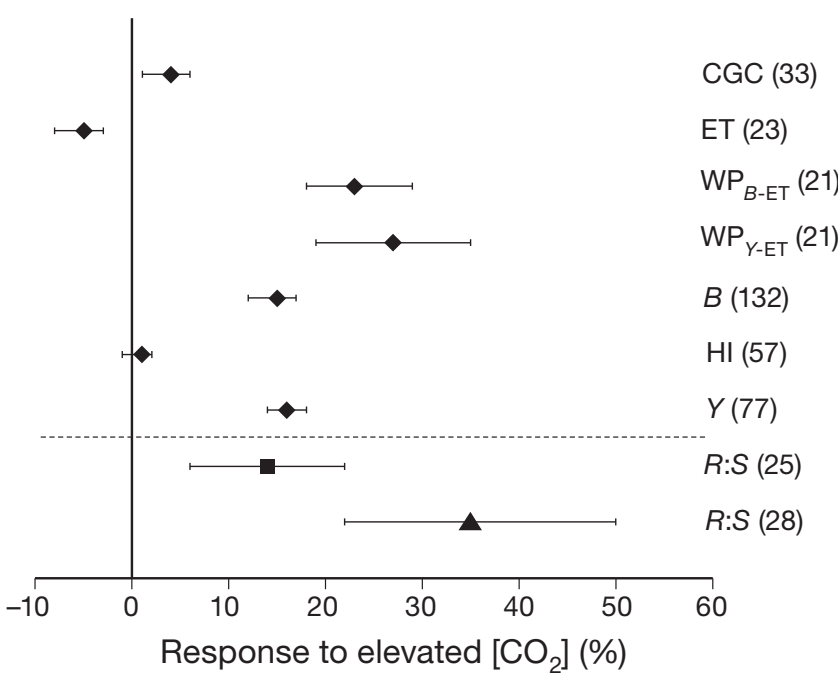

Fig. 1. Percentage change $( \pm 95 \% \mathrm{CI})$ of different variables at elevated [CO2]: (४) 541-620 $\mathrm{mmol} \mathrm{mol}^{-1}$; (口) 541-

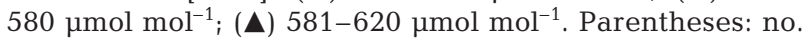
of observations contributing to each response variable. Abbreviations in Table 1

between elevated $\left[\mathrm{CO}_{2}\right]$ and ambient $\left[\mathrm{CO}_{2}\right]$ conditions (Fig. 2). Negative values indicate an acceleration of development at elevated $\left[\mathrm{CO}_{2}\right]$. Although statistically significant, the responses were small: $-1.9 \mathrm{~d}$ for $A$ (for $\left[\mathrm{CO}_{2}\right]=468$ to $662 \mu \mathrm{mol} \mathrm{mol}^{-1}$ ) and $-1.6 \mathrm{~d}$ for $M$ (for $\left[\mathrm{CO}_{2}\right]=541$ to $620 \mu \mathrm{mol} \mathrm{mol}^{-1}$ ) (Fig. 2).

The general findings present a useful image of the overall impact of elevated $\left[\mathrm{CO}_{2}\right]$ on crop development and production. However, they do not reveal underlying patterns of variation in the effect size.

\subsection{The influence of $\left[\mathrm{CO}_{2}\right]$ level}

For CGC, ET and $\mathrm{WP}_{\mathrm{ET}}$ all the observations fell in the elevated $\left[\mathrm{CO}_{2}\right]$ range of 541 to $580 \mu \mathrm{mol} \mathrm{mol}^{-1}$, and partitioning the datasets according to different

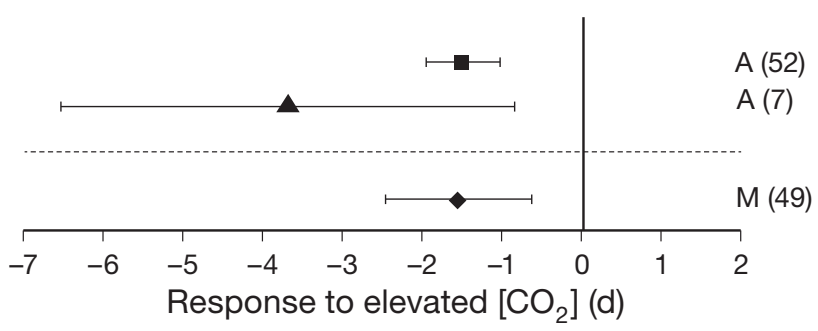

Fig. 2. Phenological response (anthesis, $A_{i}$ maturity, $M$ ) to elevated $\left[\mathrm{CO}_{2}\right]$. Mean difference $( \pm 95 \% \mathrm{CI})$ between elevated and ambient $\left[\mathrm{CO}_{2}\right]:(\diamond) 541-620 \mu \mathrm{mol} \mathrm{mol}^{-1}$; (ロ) 541$580 \mu \mathrm{mol} \mathrm{mol}^{-1}$; (A) 581-620 $\mu \mathrm{mol} \mathrm{mol}^{-1}$. Parentheses: no. of observations for each response variable. Abbreviations in Table 1 
$\left[\mathrm{CO}_{2}\right]$ levels was not necessary. Of the remaining variables, the increase in response magnitude with rising $\left[\mathrm{CO}_{2}\right]$ level was only significant for $R: S$ and $A$ (Table 2). R:S increased by $14 \%$ for elevated $\left[\mathrm{CO}_{2}\right]$ between 541 and $580 \mu \mathrm{mol} \mathrm{mol}^{-1}$. The response grew to $35 \%$ when $\left[\mathrm{CO}_{2}\right]$ was as high as 581 to $620 \mu \mathrm{mol}$ $\mathrm{mol}^{-1}$ (Fig. 1). A shifted earlier by $1.5 \mathrm{~d}$ for elevated $\left[\mathrm{CO}_{2}\right]$ values between 541 and $580 \mu \mathrm{mol} \mathrm{m^{-1 }}$. Higher $\left[\mathrm{CO}_{2}\right]$ (581 to $620 \mu \mathrm{mol} \mathrm{mol}^{-1}$ ) increased the earlier occurrence to $3.7 \mathrm{~d}$ (Fig. 2).

\subsection{The influence of environmental stress}

A few responses showed significant differences according to environmental conditions, i.e. water and nitrogen availability. Water stress was only a source

Table 2. Between-group $\left(Q_{\mathrm{b}}\right)$ and total $\left(Q_{\mathrm{T}}\right)$ heterogeneity for $\mathrm{CO}_{2}$ effect size for $\left[\mathrm{CO}_{2}\right]$ level categories. Response variables were represented by $k$ observations. ${ }^{*} \mathrm{p} \leq 0.05$. n.a.: absence of data in certain categories. See Table 1 for definitions

\begin{tabular}{|lccc|}
\hline \multirow{2}{*}{ Variable } & \multicolumn{3}{c|}{$\left[\mathrm{CO}_{2}\right]$ level } \\
\cline { 2 - 4 } & $Q_{\mathrm{b}}$ & $Q_{\mathrm{T}}$ & $k$ \\
\hline $\mathrm{ET}$ & n.a. & n.a. & - \\
$\mathrm{WP}_{B \text {-ET }}$ & n.a. & n.a. & - \\
$\mathrm{WP}_{Y \text {-ET }}$ & n.a. & n.a. & - \\
$R: S$ & $0.40^{*}$ & 3.38 & 53 \\
$B$ & 0.00 & 2.29 & 132 \\
$\mathrm{HI}$ & 0.00 & 0.19 & 57 \\
$Y$ & 0.00 & 0.88 & 77 \\
$\mathrm{CGC}$ & n.a. & n.a. & - \\
$A$ & $6.62^{*}$ & 67.79 & 59 \\
$M$ & 0.18 & 45.19 & 48 \\
\hline
\end{tabular}

of variation in the response of the maturity date (Table 3). $M$ shifted forward by $2.6 \mathrm{~d}$ for wellwatered crops under elevated $\left[\mathrm{CO}_{2}\right]$ (541 to $620 \mu \mathrm{mol}$ $\mathrm{mol}^{-1}$ ), but no effect was detected for water stressed crops (Fig. 3). Soil nitrogen availability caused differences in biomass responses (B) to elevated $\left[\mathrm{CO}_{2}\right]$ (Fig. 4). Crops provided with sufficient nitrogen benefitted more $(+18 \%)$ from elevated $\left[\mathrm{CO}_{2}\right]$ (541 to $620 \mu \mathrm{mol} \mathrm{mol}^{-1}$ ) than crops that experienced nitrogen deficiency $(+9 \%)$.

\subsection{The influence of crop photosynthetic type}

Effect sizes of CGC, ET, WP, $B$ and HI did not differ significantly between photosynthetic type sub-

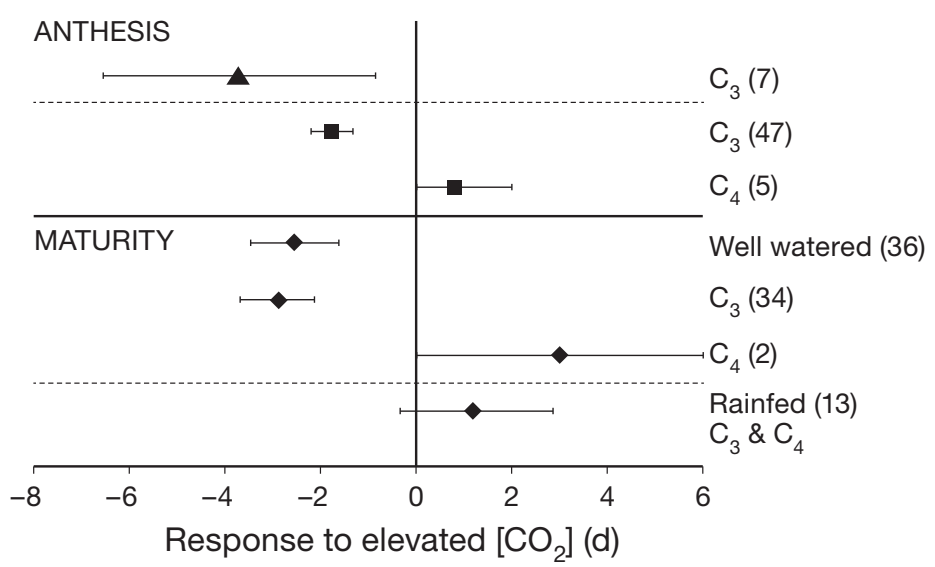

Fig. 3. Effect of crop type and water stress on phenological responses to elevated $\left[\mathrm{CO}_{2}\right]$. Mean difference $( \pm 95 \% \mathrm{CI})$ between elevated $\left[\mathrm{CO}_{2}\right]$ and ambient $\left[\mathrm{CO}_{2}\right]$ : $(\diamond)$ 541-620 $\mu \mathrm{mol}$

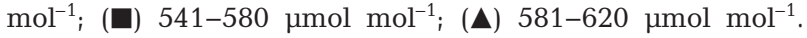
Parentheses: no. of observations for each response variable

Table 3. Between group $\left(Q_{\mathrm{b}}\right)$ and total $\left(Q_{\mathrm{T}}\right)$ heterogeneity for $\mathrm{CO}_{2}$ effect size for water stress, nitrogen stress and crop type categories. Response variables were represented by $k$ observations. ${ }^{*} p \leq 0.05,{ }^{* *} p \leq 0.01$; n.a.: absence of data in certain categories. See Table 1 for definitions

\begin{tabular}{|c|c|c|c|c|c|c|c|c|c|}
\hline \multirow[t]{2}{*}{ Variable } & \multicolumn{3}{|c|}{ Water stress } & \multicolumn{3}{|c|}{ Nitrogen stress } & \multicolumn{3}{|c|}{ Crop type } \\
\hline & $Q_{\mathrm{b}}$ & $Q_{\mathrm{T}}$ & $k$ & $Q_{\mathrm{b}}$ & $Q_{\mathrm{T}}$ & $k$ & $Q_{\mathrm{b}}$ & $Q_{\mathrm{T}}$ & $k$ \\
\hline ET & 0.00 & 0.07 & 23 & 0.00 & 0.07 & 23 & 0.00 & 0.07 & 23 \\
\hline $\mathrm{WP}_{B \text {-ET }}$ & 0.00 & 0.24 & 21 & 0.03 & 0.24 & 21 & 0.01 & 0.24 & 21 \\
\hline $\mathrm{WP}_{Y \text {-ET }}$ & 0.00 & 0.45 & 21 & 0.04 & 0.45 & 21 & 0.03 & 0.45 & 21 \\
\hline$R: S\left(541-580 \mu \mathrm{mol} \mathrm{mol}{ }^{-1}\right)$ & 0.01 & 0.82 & 25 & 0.00 & 0.82 & 25 & n.a. & n.a. & - \\
\hline$R: S\left(581-620 \mu \mathrm{mol} \mathrm{mol}{ }^{-1}\right)$ & n.a. & n.a. & - & 0.01 & 2.15 & 28 & n.a. & n.a. & - \\
\hline$B$ & 0.00 & 2.29 & 132 & $0.18^{* *}$ & 2.29 & 132 & 0.02 & 2.29 & 132 \\
\hline HI & 0.00 & 0.19 & 57 & 0.00 & 0.19 & 57 & 0.00 & 0.19 & 57 \\
\hline$Y$ & 0.00 & 0.90 & 79 & 0.00 & 0.90 & 79 & $0.04^{*}$ & 0.90 & 79 \\
\hline CGC & 0.59 & 7.18 & 33 & 1.72 & 7.18 & 33 & 0.26 & 7.18 & 33 \\
\hline$A\left(541-580 \mu \mathrm{mol} \mathrm{mol}{ }^{-1}\right)$ & 0.02 & 51.2 & 52 & 0.20 & 51.6 & 52 & $13.29^{* *}$ & 66.03 & 52 \\
\hline$A\left(581-620 \mu \mathrm{mol} \mathrm{mol}^{-1}\right)$ & 0.88 & 6.52 & 7 & 0.02 & 5.56 & 7 & n.a. & n.a. & - \\
\hline$M$ & $16.19^{* *}$ & 62.85 & 49 & 1.86 & 48.32 & 49 & $17.39^{* *}$ & 64.88 & 49 \\
\hline
\end{tabular}




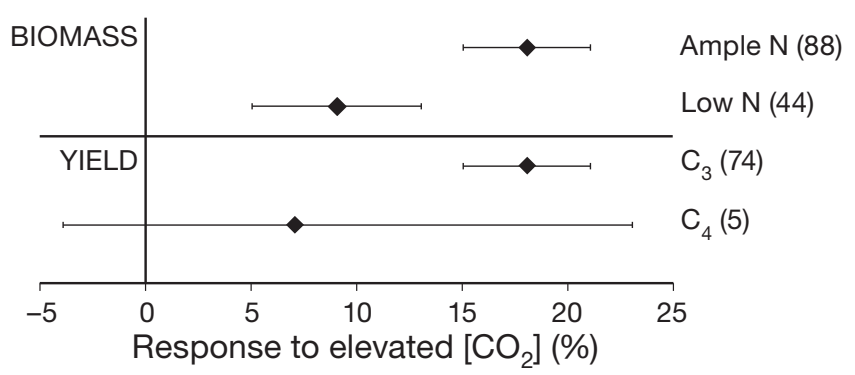

Fig. 4. Percentage change $( \pm 95 \% \mathrm{CI})$ in biomass and yield (in response to $\left[\mathrm{CO}_{2}\right]$ elevated to $541-620 \mu \mathrm{mol} \mathrm{mol}^{-1}$ ), according to crop type and nitrogen stress level. Parentheses: no. of observations for each response variable

groups. But significant differences existed between the subgroups for phenological parameters and yield (Table 3). Whilst C3 crops shifted $A$ and $M$ earlier in well-watered conditions, C4 crops always postponed their phenological development (Fig. 3). In water limiting conditions, water stress masked the effect of elevated $\left[\mathrm{CO}_{2}\right]$ on $M$ of $\mathrm{C} 3$ crops. Yield increased substantially for C3 crops (+18\%), but C4 crops did not significantly benefit from the $\mathrm{CO}_{2}$ fertilization (Fig. 4).

\section{DISCUSSION}

The present meta-analysis quantified the positive $\mathrm{CO}_{2}$ effect on above-ground biomass and yield production that will have an impact on global food production. Yet, most notable was the improvement in water productivity and the increase in $R: S$ ratio.

\subsection{Crop water relations}

\subsubsection{Water productivity}

The most critical result of this meta-analysis was the robust and strong response of the water productivity to elevated $\left[\mathrm{CO}_{2}\right]$. This has major implications for crop production in water-scarce areas and can be a positive prospect considering possible deteriorations in water availability related to global change. Crop modellers that use water-driven models should consider this major effect.

The improvement for C3 crops found in the present study corresponded with reported meta-analytical results for the increase in leaf-level water use efficiency (instantaneous transpiration efficiency, ITE) by Ainsworth \& Long (2005). However, ITE does not take into account potential feedback mechanisms on a field-scale due to increased leaf area or canopy structure. Results for ITE are thus not directly comparable with the water productivity on field-scale. ITE increased for $\mathrm{C} 3$ crops by $68 \%$ at elevated $\left[\mathrm{CO}_{2}\right]$

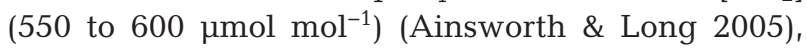
more than proportionally in comparison to responses on the canopy-scale found in the present study. The positive response demonstrated in the present analysis was consistent with individual experiments and the findings of Leakey et al. (2009) regarding reduced water use (see Section 4.1.2), and was apparent in both well-watered and rainfed conditions.

In the present meta-study, no differences were found between the water productivity responses of the C4 crop sorghum and the responses of C3 crops. The data on sorghum originate from a study performed by Conley et al. (2001) who reported a watersaving effect with no extra production in wellwatered conditions against a water use status-quo in combination with a prolonged crop cycle in dry conditions. Leakey (2009) confirmed the hypothesis of improved water productivity at macro-scale of C4 species by a conceptual model that linked the decrease in stomatal conductance at elevated $\left[\mathrm{CO}_{2}\right]$ with the reduction of whole-plant water use. At the smaller leaf-scale, similar results were found by Wand et al. (1999) on the increase of the ITE of C4 grasses at elevated $\left[\mathrm{CO}_{2}\right]$. Conversely, Ainsworth \& Long (2005) did not detect an increase in leaf-level water use efficiency for $\mathrm{C} 4$ crops but ascribed this to the possible inadequacy of the data considered.

\subsubsection{Evapotranspiration}

The overall evapotranspiration response to elevated $\left[\mathrm{CO}_{2}\right]$ was smaller than the water productivity response but also robust for crop type and environmental stress. The 5\% decrease reflected several effects. Elevated $\left[\mathrm{CO}_{2}\right]$ decreased crop transpiration via reductions in stomatal conductance (e.g. Kimball et al. 2002, Ainsworth \& Long 2005, Ainsworth \& Rogers 2007, Leakey et al. 2009), thus decreasing the transpiration on a leaf area basis. This mechanism reduces the cooling effect of the transpiration process, augments leaf temperature and triggers more transpiration, hence offsetting part of the transpiration reduction. Moreover, increased biomass production and leaf area can increase the total crop transpiration on the field-scale (Kimball et al. 1999, 2002).

Wand et al. (1999) considered the transpiration reduction as 'the most ubiquitous response for almost all plant types' (Wand et al. 1999, p 731) and stressed 
the positive effect on the water balance on a larger scale. The results of their meta-analysis show that reduced stomatal conductance at the leaf level, which has been subject of several field experiments and meta-analyses, was not translated to a proportional reduction in evapotranspiration on a larger scale. However, the reduction effect, although small, was statistically significant, which was corroborated by the findings of the present meta-analysis. All this is also in line with the conclusions of Leakey et al. (2009) about the improvement of the soil moisture availability when plants grow at elevated $\left[\mathrm{CO}_{2}\right]$.

\subsection{Biomass and yield production}

Crops benefit from elevated $\left[\mathrm{CO}_{2}\right]$ for the production of above- and belowground biomass and yield. This results from the direct stimulating effect of $\mathrm{CO}_{2}$ on photosynthesis of $\mathrm{C} 3$ crops through acceleration of carboxylation and suppression of respiration (Long et al. 2004, Ainsworth \& Rogers 2007). Indirect effects through improved water relations and nutrient relations, provided that enough nutrients are available, can stimulate growth of both C3 and C4 species (Wand et al. 1999, Kimball et al. 2002, Long et al. 2006, Wall et al. 2006, Leakey et al. 2009).

\subsubsection{Biomass production}

The general increase in biomass between 12 and $17 \%$ at elevated $\left[\mathrm{CO}_{2}\right]$ in FACE (541 to $620 \mu \mathrm{mol}$ $\mathrm{mol}^{-1}$ ) found in the present study was consistent with the results for rice $(12 \%)$ and wheat $(13 \%)$, but somewhat smaller than the average biomass increase of $24 \%$ for legumes as determined by Long et al. (2006) for elevated $\left[\mathrm{CO}_{2}\right]$ of $550 \mu \mathrm{mol} \mathrm{mol}{ }^{-1}$. Ainsworth \& Long (2005) reported a similar increase of $10 \%$ for C3 grasses and mentioned a higher increase for legumes for $\left[\mathrm{CO}_{2}\right]$ between 475 and $600 \mu \mathrm{mol} \mathrm{mol}{ }^{-1}$. Our study did not differentiate between leguminous and others species since both have the same carbon-fixing mechanism, and should theoretically respond similarly to elevated $\left[\mathrm{CO}_{2}\right]$. The ability of legumes to fix nitrogen led them to be grouped in the category of crops grown with sufficient nitrogen resources.

The present analysis revealed differences in biomass production responses between subgroups formed according to nitrogen availability. When nitrogen is not limiting, crops benefit fully from elevated $\left[\mathrm{CO}_{2}\right]$ for biomass production. Yet, due to enhanced growth at elevated $\left[\mathrm{CO}_{2}\right]$, crops may face an acute nitrogen limitation if the nitrogen availability is not tailored to the increased demand for nitrogen. If the crops experience nitrogen deficiency, the total protein concentration within the plant reduces and the activity of ribulose-1,5-bisphosphate carboxylase oxygenase (Rubisco) and other enzymes involved in the photosynthesis process decreases, resulting in a lower photosynthesis rate (Stitt \& Krapp 1999). Thus, nitrogen deficiency that can be exacerbated by effects from elevated $\left[\mathrm{CO}_{2}\right]$ can annul the beneficial direct effect of this $\left[\mathrm{CO}_{2}\right]$ increase on photosynthesis. This inhibiting effect of nutrient deficiency is often more important than a potential positive effect of improved nitrogen use efficiency. The improved nitrogen use efficiency results from the reduced investment of nitrogen in the processes of photosynthesis at elevated $\left[\mathrm{CO}_{2}\right]$, at which a certain photosynthesis rate can be achieved with lower activities of Rubisco (Stitt \& Krapp 1999). Simultaneously, nitrogen deficiency induces a sugar mediated repression of enzymes affecting the crop's sink metabolism, i.e. the capacity to generate new sinks for carbon storage (Stitt \& Krapp 1999). The differences between categories of nitrogen availability were not reported in prior metaanalyses but corroborate with results for grass species grown in low nutrient conditions (Wand et al. 1999, Ainsworth \& Long 2005).

The present analysis showed no differences in biomass production response between categories made according to water availability. Rainfed crops were equally well stimulated at elevated $\left[\mathrm{CO}_{2}\right]$, and stomatal closure diminished the adverse effect of limited water resources. Yet, the mechanism behind the stimulatory effect can be different. Whilst in conditions without water stress, increased photosynthesis is the main mechanism of increased production, in water limiting conditions the (partial) elimination of water stress due to decreased evapotranspiration and increased water productivity is an important factor.

The absence of differences in biomass responses related to photosynthetic type was notable. Prior meta-studies (e.g. Ainsworth \& Long 2005, Long et al. 2006, Ainsworth \& Rogers 2007) found that C4 species do not respond to elevated $\left[\mathrm{CO}_{2}\right]$ with regard to aboveground biomass production. Potential differences in responses of $\mathrm{C} 3$ and $\mathrm{C} 4$ crops originate from differences in photosynthetic characteristics. In $\mathrm{C} 3$ plants, elevated $\left[\mathrm{CO}_{2}\right]$ will increase the rate and efficiency of photosynthesis because the plants operate below their optimum $\mathrm{CO}_{2}$ level at current $\left[\mathrm{CO}_{2}\right]$. In contrast, elevated $\left[\mathrm{CO}_{2}\right]$ is not expected to have a strong direct impact on the photosynthesis process of $\mathrm{C} 4$ plants because they are considered to be $\mathrm{CO}_{2}$ sat- 
urated at current $\left[\mathrm{CO}_{2}\right]$ when other resources are adequately present (Bowes 1993). The potential responsiveness of $\mathrm{C} 4$ plants to elevated $\left[\mathrm{CO}_{2}\right]$ is presumed to arise primarily through improved water relations (Leakey 2009). Elevated $\left[\mathrm{CO}_{2}\right]$ in combination with limited water availability can stimulate biomass production indirectly via the mitigation of drought stress, as photosynthesis can be maintained longer into a drought period due to water conservation. If root growth is stimulated, this facilitates the exploitation of water and nutrients in deeper soil layers, and mitigates against moisture stress in rainfed conditions (Kimball et al. 2002). Leakey et al. (2006) questioned whether the indirect drought alleviating effect of elevated $\left[\mathrm{CO}_{2}\right]$ can negate negative effects of increasing temperatures and drought in the future, without direct photosynthetic stimulation effect. In the present study, no significant differences could be detected between $\mathrm{C} 3$ and $\mathrm{C} 4$ species categories, and between categories of water stress level for $\mathrm{C} 4$ crops. Yet, the underrepresentation of $\mathrm{C} 4$ crops in the database might have confounded the results (for a more thorough discussion see Section 4.4).

Belowground biomass production was also stimulated by elevated $\left[\mathrm{CO}_{2}\right]$ and disproportionately so relative to aboveground biomass. The $R: S$ ratio increased, and the stimulation increased with increasing $\left[\mathrm{CO}_{2}\right]$. Rogers et al. (1996) reviewed the response of the $R: S$ ratio of crops grown under elevated $\left[\mathrm{CO}_{2}\right]$ under different fumigation methods and concluded that in majority of the cases the $R: S$ ratio increased, but responses were highly variable among crop species and environmental conditions. Elevated $\left[\mathrm{CO}_{2}\right]$ can lead to a shift in carbon allocation within different plant organs and to enhanced carbon storage in the soil, but detailed mechanisms for the disproportionately large stimulation of belowground biomass remain unclear (Rogers et al. 1996). The changed $R: S$ ratio may be a direct effect of elevated $\left[\mathrm{CO}_{2}\right]$, but also the indirect effect through altered resource availability (both water and nitrogen) may lead to changes in $R: S$ ratio (Rogers et al. 1996). The present study supported the hypothesis that the $R: S$ ratio increases on average, and heterogeneity tests could not reveal major differences between crop type or environmental conditions.

\subsubsection{Yield}

Mean yield increases for $\mathrm{C} 3$ crops $(+17 \%)$ in FACE environments (541 to $620 \mu \mathrm{mol} \mathrm{mol}^{-1}$ ) were slightly higher than results reported by Long et al. (2006) (12 to $14 \%$ at $550 \mu \mathrm{mol} \mathrm{mol}^{-1}$ ) and similar to the results of Ainsworth \& Long (2005) $(17 \%$ at 475 to $600 \mu \mathrm{mol}$ $\mathrm{mol}^{-1}$ ). The average yield stimulation in the present study included a number of FACE experiments on hybrid rice cultivars (Liu et al. 2008, Yang et al. $2009 a, b)$ that exhibited a much larger yield response to $\mathrm{CO}_{2}$ compared with prior studies on japonica rice cultivars. This invites further experimentation to clarify the characteristics of crops or environments with higher responses to $\mathrm{CO}_{2}$ fertilization. The absence of a significant yield increase for $\mathrm{C} 4$ crops agreed with findings reported elsewhere (Long et al. 2006), although the average effect found in the present study $(+7 \%)$ was higher. The broad confidence interval could be explained by the low number of observations for $\mathrm{C} 4$ species (for a more thorough discussion see Section 4.4) and the high variability of responses due to differences in water availability, although the latter was not strong enough to detect statistically significant differences between categories formed according to water stress level.

In contrast with the differences in biomass response found for different categories of nitrogen availability, no heterogeneity in yield response could be detected. This contrasts with conclusions of Ainsworth \& Long (2005) who found that limited nitrogen resources reduced the response to $\mathrm{CO}_{2}$. Some recent studies (Liu et al. 2008, Yang et al. 2009b, Manderscheid et al. 2009, 2010) that are part of the database of the present meta-analysis examined crop responses under low nitrogen availability and reported a stimulation of yield by elevated $\left[\mathrm{CO}_{2}\right]$ that was similar to that for fertile conditions.

$\mathrm{HI}$ was not affected by elevated $\left[\mathrm{CO}_{2}\right]$ up to $620 \mu \mathrm{mol} \mathrm{mol}{ }^{-1}$. This result held for both crop types, with or without environmental stress. HI was not studied explicitly for a broad range of crops in prior meta-analyses in FACE conditions, but the similarity between the stimulation magnitude of biomass and yield production suggested no significant harvest index response.

\subsection{Crop development}

\subsubsection{Canopy development}

Although lesser than responses of crop water relations and production, the CGC during early development increased at elevated $\left[\mathrm{CO}_{2}\right]$ (541 to $580 \mu \mathrm{mol}$ $\mathrm{mol}^{-1}$ ) as a result of photosynthesis stimulation. This enables crops to close the canopy earlier, is beneficial for light capture, and reduces soil evaporation. Nutri- 
ent or water status of the soil did not affect the response to $\mathrm{CO}_{2}$ in this early stage when resources may not yet be seriously limiting.

The increase of CGC of the C4 crop sorghum was noteworthy for its similarity with the trend for $\mathrm{C} 3$ crops. Data came from 4 independent observations of Ottman et al. (2001) who did not discuss the stimulation of early C4 development. Cousins et al. (2003) showed that in very young sorghum leaves, photosynthesis occurs as in $\mathrm{C} 3$ plants and can thus be responsive to $\left[\mathrm{CO}_{2}\right]$. However by the time the young leaves emerge from the whorl, $\mathrm{C} 4$ photosynthesis is fully expressed.

A consistency check of our results with prior analyses was difficult to make because most analyses investigated the full course of canopy development, including later growth stages. Ainsworth \& Long (2005) analyzed LAI response and detected no increase of LAI for C3 grasses, but did not mention the effect on crops. Meta-analyses on soybean (Ainsworth et al. 2002) and rice (Ainsworth 2008), on the other hand, detected increases in LAI (>10\%) of the respective crops but included chamber experiments in the analysis, which are assumed to overestimate the $\mathrm{CO}_{2}$ effect (Ainsworth et al. 2008b, Leakey et al. 2009).

\subsubsection{Phenological development}

Parallel to accelerated canopy development, phenological development ( $A$ and $M$ ) of $C 3$ crops was accelerated. The shift in phenology might be directly linked to accelerated growth per se (Wery 2005), or to an alternate mechanism of increased leaf temperature due to reduced evapotranspiration (Blum 1996).

In contrast with the response magnitude of CGC and $A$, for which severe stress could not develop, water stress affected maturity responses and thus cycle length. Well-watered C3 crops shifted Mearlier in analogy with advanced canopy closure and earlier $A$. In water limiting conditions however, the response might be masked by water stress. Strategies used by plants to avoid negative effects of moisture stress by shifting maturity earlier (McMaster et al. 2008) were not enhanced by elevated $\left[\mathrm{CO}_{2}\right]$. $\mathrm{C} 4$ crops did not translate accelerated canopy development into accelerated phenological development. C4 crops tend to postpone anthesis and maturity, thus prolonging the growing cycle. Also in case of $\mathrm{C} 4$ crops, the shift in phenological development may be related to interactions with water stress. Because elevated $\left[\mathrm{CO}_{2}\right]$ improves the crop water productivity, water stress may occur later in the season and crops may survive longer. No difference could be detected between the responses of well-watered and water stressed $\mathrm{C} 4$ crops, but the low number of observations may have prevented the detection of differences between the categories.

The present study provides for the first time an overview of the developmental responses of crops to elevated $\left[\mathrm{CO}_{2}\right]$ after individual studies mentioned variable effects. Although significant, the changes were minor and less important than the effect on crop water relations. However, some authors (e.g. Pinter et al. 2000) caution that confounding micro-climate effects in FACE experiments with blowers may induce artificial developmental acceleration.

\subsection{Data limitations}

The above results should be understood within the context of meta-analyses. A recognized problem related to meta-analysis is publication bias, which refers to the gap between published research results and 'real' research results, i.e. the results of all the conducted research in a certain area, published or not (Rothstein et al. 2005). Publication bias was evaluated for all the datasets using normal quantile plots as suggested by Wang \& Bushman (1998) instead of funnel plots because of easier interpretation. Most of the normal quantile plots did not show serious evidence of publication bias, except for the variable $\mathrm{WP}_{B \text {-ET }}$ (data not shown). Not a single study reported a change equal or close to zero for $\mathrm{WP}_{B \text {-ET }}$. This may make the set questionable. Does it indicate that the variable is highly susceptible to $\mathrm{CO}_{2}$ ? Or have non-significant results been omitted? Future FACE studies focusing on water productivity, thereby controlling against nonpublication of potential non-significant results, may confirm or adjust the results of our study. There was no evidence for potential publication bias associated with phenology, but since changes are more likely to be reported than a status-quo, one has to be on the alert for the risk of publication bias.

The power to draw statistical conclusions after data categorization may be restricted by the limited number of observations in certain categories. This was particularly true for categorization according to crop type. Results may be biased by the fact that studies on $\mathrm{C} 4$ crops were underrepresented as compared to $\mathrm{C} 3$ crops. Because researchers expect $\mathrm{C} 4$ crops to benefit less from elevated $\left[\mathrm{CO}_{2}\right]$, experiments on $\mathrm{C} 4$ crops are less common. For some variables, no data 
were available for C4 crops. Leakey (2009) estimated that the proportion of the research output on $\mathrm{C} 4$ responses to elevated $\left[\mathrm{CO}_{2}\right]$ was $<20 \%$, while $\mathrm{C} 4$ crops are responsible for $40 \%$ of the global grain harvest and make even a higher contribution to agricultural production in particular countries. Future FACE experiments on $\mathrm{C} 4$ species are desirable to draw robust conclusions about responses of staple crops like maize and sorghum to elevated $\left[\mathrm{CO}_{2}\right]$. Within the group of $\mathrm{C} 3$ crops, wheat and rice are disproportionately overrepresented compared to other $\mathrm{C} 3$ species. Although all C3 species follow the same photosynthetic pathway-which exhibits a considerable response to elevated [CO2], and thus the general $\mathrm{C} 3$ responses can be assumed to be representative for different C3 species - better representation of other C3 species in FACE experiments and future metaanalyses is desirable to verify the former assumption and identify potential underlying species-specific effects.

The process of categorization also entailed other complications. Data were grouped according to water stress level. Based on irrigation management reported in primary studies, a distinction was made between rainfed and irrigated treatments, as such attempting to discriminate between stressed and nonstressed crops. The validity of this reasoning depends for rainfed crops on soil and weather characteristics, and for irrigated crops on the appropriateness of the experimental irrigation management. Both may be problematic to evaluate by meta-analysts. From the primary data it could be deduced that all rainfed crops that were part of the study experienced a certain level of water stress at least during part of the growing season. The (full) irrigation treatments were designed in the primary experiments to avoid water stress. An analogous argument applies to nitrogen stress levels.

Although higher $\mathrm{CO}_{2}$ stimulation with higher $\left[\mathrm{CO}_{2}\right]$ is presumed, be it up to a certain level (Ainsworth \& Long 2005, Long et al. 2005, Ainsworth \& Rogers 2007), no consistent variation in effect size due to $\left[\mathrm{CO}_{2}\right]$ level could be detected in our study. Prior meta-analyses for one crop, including studies with different fumigation methods, reported consistent trends towards higher $\mathrm{CO}_{2}$ effects with higher treatment concentrations for above- and belowground biomass or yield production (e.g. Ainsworth et al. 2002, Ainsworth 2008). The absence of variation in effect size in our meta-analysis may be confounded by the features of the FACE studies included in the analysis. Most experiments were conducted at elevated $\left[\mathrm{CO}_{2}\right]$ between 540 and $580 \mathrm{umol} \mathrm{mol}^{-1}$. The absolute difference between discrete classes of $\left[\mathrm{CO}_{2}\right]$ was smaller than in other meta-analyses, where $\left[\mathrm{CO}_{2}\right]$ up to $700 \mu \mathrm{mol} \mathrm{mol}^{-1}$ were more common and thus variation in effect size could be more easily detected.

\section{CONCLUSION}

This meta-analysis corroborates that elevated $\left[\mathrm{CO}_{2}\right]$ substantially affects various macro-growth processes of agricultural crops and has a beneficial impact on water productivity and crop yield. The specific effects on individual variables involved in structural growth processes were quantified in this meta-analysis and can serve as a guideline for crop modellers to tune modelling tools. Modellers should consider the positive yield and biomass responses to elevated $\left[\mathrm{CO}_{2}\right]$, mainly for $\mathrm{C} 3$ crops. Equally important, but hitherto given less emphasis in models, was the change in $R: S$ ratio under influence of elevated $\left[\mathrm{CO}_{2}\right]$. As the mechanisms behind this effect are not completely understood, more FACE experiments unraveling the response of $R: S$ ratio and belowground biomass production are required to translate this effect into model equations. A change in the $R: S$ ratio can change the water and nutrient uptake. In relation to water resources, the field-scale ET responsewhich was smaller than proportional to stomatal closure but nonetheless demonstrated to be significant - and the substantial increase of water productivity of both $\mathrm{C} 3$ and $\mathrm{C} 4$ crops are important outcomes for modellers. An additional advance brought by this meta-analysis is the overview it provides of the change in timing of $A$ and $M$ as influenced by elevated $\left[\mathrm{CO}_{2}\right]$.

More field work that can serve as a basis to optimize models is still desirable. With this, it is essential to examine firstly the isolated effect of elevated $\left[\mathrm{CO}_{2}\right]$ and secondly the interactions with other environmental factors, thereby carefully identifying the water, nutrient and other potential stress levels. With optimized and carefully validated models, the effect of interactions of elevated $\left[\mathrm{CO}_{2}\right]$ with other climatic factors (e.g. temperature, rainfall, evaporative demand of the atmosphere) on agricultural crops can be further explored and lead to projections of global food production. Some of the predominantly positive effects of elevated $\left[\mathrm{CO}_{2}\right]$ alone, including improved water productivity and increased yield, may then be counteracted by negative effects of elevated temperatures and modifications of other weather variables. 
Acknowledgements. We are grateful to the Research Foundation-Flanders (FWO) for funding E.V. with a PhD fellowship. We thank the anonymous reviewers for their valuable comments on earlier versions of this paper.

\section{LITERATURE CITED}

Adams DC, Anthony CD (1996) Using randomization techniques to analyse behavioural data. Anim Behav 51: 733-738

Adams DC, Gurevitch J, Rosenberg MS (1997) Resampling tests for meta-analysis of ecological data. Ecol 78: $1277-1283$

Ainsworth EA (2008) Rice production in a changing climate: a meta-analysis of responses to elevated carbon dioxide and elevated ozone concentration. Glob Change Biol 14: $1642-1650$

Ainsworth EA, Long SP (2005) What have we learned from 15 years of free-air $\mathrm{CO}_{2}$ enrichment (FACE)? A metaanalytic review of the responses of photosynthesis, canopy properties and plant production to rising $\mathrm{CO}_{2}$. New Phytol 165:351-371

Ainsworth EA, Rogers A (2007) The response of photosynthesis and stomatal conductance to rising $\left[\mathrm{CO}_{2}\right]$ : mechanisms and environmental interactions. Plant Cell Environ 30:258-270

Ainsworth EA, Davey P, Bernacchi C, Dermody O, Heaton E, Moore D (2002) A meta-analysis of elevated $\left[\mathrm{CO}_{2}\right]$ effects on soybean (Glycine max) physiology, growth and yield. Glob Change Biol 8:695-709

> Ainsworth EA, Beier C, Calfapietra C, Ceulemans R and others (2008a) Next generation of elevated $\left[\mathrm{CO}_{2}\right]$ experiments with crops: a critical investment for feeding the future world. Plant Cell Environ 31:1317-1324

Ainsworth EA, Leakey ADB, Ort DR, Long SP (2008b) FACE-ing the facts: inconsistencies and interdependence among field, chamber and modeling studies of elevated $\left[\mathrm{CO}_{2}\right]$ impacts on crop yield and food supply. New Phytol 179:5-9

Benbi DK, Nieder R (eds) (2003) Handbook of processes and modeling in the soil-plant system. The Haworth Press, Binghamton, NY

Blum A (1996) Crop responses to drought and the interpretation of adaptation. Plant Growth Regul 20:135-148

Borenstein M, Hedges LV, Higgins JPT, Rothstein HR (2009) Introduction to meta-analysis. John Wiley \& Sons, Chichester

Bowes G (1993) Facing the inevitable: plants and increasing atmospheric $\mathrm{CO}_{2}$. Annu Rev Plant Physiol Plant Mol Biol 44:309-332

Conley MM, Kimball BA, Brooks TJ, Pinter PJ and others (2001) CO2 enrichment increases water-use efficiency in sorghum. New Phytol 151:407-412

Cooper HM, Hedges LV (1994) The handbook of research synthesis. Russell Sage Foundation, New York, NY

Cousins AB, Adam NR, Wall GW, Kimball BA and others (2003) Development of C4 photosynthesis in sorghum leaves grown under free-air $\mathrm{CO}_{2}$ enrichment (FACE). J Exp Bot 54:1969-1975

Curtis P, Wang X (1998) A meta-analysis of elevated $\mathrm{CO}_{2}$ effects on woody plant mass, form, and physiology. Oecologia 113:299-313

> Drake BG, Gonzalezmeler MA, Long SP (1997) More efficient plants: a consequence of rising atmospheric $\mathrm{CO}_{2}$ ?
Annu Rev Plant Physiol Plant Mol Biol 48:609-639

Gurevitch J, Hedges LV (1999) Statistical issues in ecological meta-analyses. Ecol 80:1142-1149

Hedges LV, Olkin I (1985) Statistical methods for metaanalysis. Academic Press, Orlando, FL

Hedges LV, Gurevitch J, Curtis PS (1999) The meta-analysis of response ratios in experimental ecology. Ecol 80: 1150-1156

Hsiao TC, Heng L, Steduto P, Rojas-Lara B, Raes D, Fereres E (2009) Aquacrop: the FAO crop model to simulate yield response to water. III. Parameterization and testing for maize. Agron J 101:448-459

IPCC (2007) Climate change: 2007 synthesis report. In: Core writing team, Pachauri, RK, Reisinger A (eds) Contribution of Working Groups I, II and III to the Fourth Assessment Report of the Intergovernmental Panel on Climate Change. IPCC, Geneva

Kimball BA, Lamorte RL, Pinter PJ, Wall GW and others (1999) Free-air $\mathrm{CO}_{2}$ enrichment and soil nitrogen effects on energy balance and evapotranspiration of wheat. Water Resour Res 35:1179-1190

Kimball BA, Kobayashi K, Bindi M (2002) Responses of agricultural crops to free-air $\mathrm{CO}_{2}$ enrichment. Adv Agron 77 : 293-368

Korner C (2003) Nutrients and sink activity drive plant $\mathrm{CO}_{2}$ responses: caution with literature-based analysis. New Phytol 159:537-538

Leakey ADB (2009) Rising atmospheric carbon dioxide concentration and the future of C4 crops for food and fuel. Proc R Soc Lond B 276:2333-2343

Leakey ADB, Ainsworth EA, Bernacchi CJ, Rogers A, Long SP, Ort DR (2009) Elevated $\mathrm{CO}_{2}$ effects on plant carbon, nitrogen, and water relations: six important lessons from FACE. J Exp Bot 60:2859-2876

> Leakey $\mathrm{ADB}$, Uribelarrea $\mathrm{M}$, Ainsworth EA, Naidu SL, Rogers A, Ort DR, Long SP (2006) Photosynthesis, productivity, and yield of maize are not affected by open-air elevation of $\mathrm{CO}_{2}$ concentration in the absence of drought. Plant Physiol 140:779-790

Liu H, Yang L, Wang Y, Huang J and others (2008) Yield formation of $\mathrm{CO}_{2}$-enriched hybrid rice cultivar Shanyou 63 under fully open-air field conditions. Field Crops Res 108:93-100

Long SP, Ainsworth EA, Rogers A, Ort DR (2004) Rising atmospheric carbon dioxide: plants face the future. Annu Rev Plant Biol 55:591-628

Long SP, Ainsworth EA, Leakey ADB, Morgan PB (2005) Global food insecurity. treatment of major food crops with elevated carbon dioxide or ozone under large-scale fully open-air conditions suggests recent models may have overestimated future yields. Philos Trans R Soc Lond B 360:2011-2020

> Long SP, Ainsworth EA, Leakey ADB, Nosberger J, Ort DR (2006) Food for thought: lower-than-expected crop yield stimulation with rising $\mathrm{CO}_{2}$ concentrations. Science 312: 1918-1921

Manderscheid R, Pacholski A, Frühauf C, Weigel HJ (2009) Effects of free air carbon dioxide enrichment and nitrogen supply on growth and yield of winter barley cultivated in a crop rotation. Field Crops Res 110:185-196

Manderscheid R, Pacholski A, Weigel HJ (2010) Effect of free air carbon dioxide enrichment combined with two nitrogen levels on growth, yield and yield quality of sugar beet: evidence for a sink limitation of beet growth under elevated $\mathrm{CO}_{2}$. Eur J Agron 32:228-239 
McLeod AR, Long SP (1999) Free-air carbon dioxide enrichment (FACE) in global change research: a review. Adv Ecol Res 28:1-56

McMaster GS, White JW, Weiss A, Baenziger PS, Wilhelm WW, Porter JR, Jamieson PD (2008) Simulating crop phenological responses to water deficits. In: Ahuja LR, Reddy VR, Saseendran SA, Yu Q (eds) Responses of crops to limited water: understanding and modeling water stress effects on plant growth processes. American Society of Agronomy, Crop Science Society of America, Soil Science Society of America, Madison, WI

Morgan PB, Ainsworth EA, Long SP (2003) How does elevated ozone impact soybean? A meta-analysis of photosynthesis, growth and yield. Plant Cell Environ 26: 1317-1328

Osenberg C, Sarnelle O, Cooper S, Holt R (1999) Resolving ecological questions through meta-analysis: goals, metrics, and models. Ecol 80:1105-1117

Ottman MJ, Kimball BA, Pinter PJ, Wall GW and others (2001) Elevated $\mathrm{CO}_{2}$ increases sorghum biomass under drought conditions. New Phytol 150:261-273

Parry ML, Rosenzweig C, Iglesias A, Livermore M, Fischer G (2004) Effects of climate change on global food production under SRES emissions and socio-economic scenarios. Glob Environ Change 14:53-67

Pinter PJ, Kimball BA, Wall GW, LaMorte RL and others (2000) Free-air CO2 enrichment (FACE): blower effects on wheat canopy microclimate and plant development. Agric Meteorol 103:319-333

Raes D, Steduto P, Hsiao TC, Fereres E (2009) Aquacrop: the FAO crop model to simulate yield response to water. II. Main algorithms and software description. Agron J 101: 438-447

Rogers HH, Prior SA, Runion GB, Mitchell RJ (1996) Root to shoot ratio of crops as influenced by $\mathrm{CO}_{2}$. Plant Soil 187: 229-248

Rosenberg MS, Adams DC, Gurevitch J (2000) MetaWin. Statistical software for meta-analysis. Sinauer Associates, Sunderland, MA

Rothstein HR, Sutton AJ, Borenstein M (2005) Publication

Editorial responsibility: Mikhail Semenov,

Harpenden, UK bias in meta-analysis. In: Rothstein HR, Sutton AJ, Borenstein $M$ (eds) Publication bias in meta-analysis: prevention, assessment and adjustments. John Wiley \& Sons, Chichester

Steduto P, Hsiao TC, Raes D, Fereres E (2009) Aquacrop: the FAO crop model to simulate yield response to water: I. Concepts and underlying principles. Agron J 101:426-437

Stitt M, Krapp A (1999) The interaction between elevated carbon dioxide and nitrogen nutrition: the physiological and molecular background. Plant Cell Environ 22:583-621

Tubiello FN, Ewert F (2002) Simulating the effects of elevated $\mathrm{CO}_{2}$ on crops: approaches and applications for climate change. Eur J Agron 18:57-74

Wall GW, Garcia RL, Kimball BA, Hunsaker DJ and others (2006) Interactive effects of elevated carbon dioxide and drought on wheat. Agron J 98:354-381

Wand SJE, Midgley GF, Jones MH, Curtis PS (1999) Responses of Wild C4 and C3 grass (Poaceae) species to elevated atmospheric $\mathrm{CO}_{2}$ concentration: a metaanalytic test of current theories and perceptions. Glob Change Biol 5:723-741

Wang MC, Bushman BJ (1998) Using the normal quantile plot to explore meta-analytic data sets. Psychol Methods 3:46-54

> Wang X (2007) Effects of species richness and elevated carbon dioxide on biomass accumulation: a synthesis using meta-analysis. Oecologia 152:595-605

Wery J (2005) Differential effects of soil water deficit on the basic plant functions and their significance to analyse crop responses to water deficit in indeterminate plants. Aust J Agric Res 56:1201-1209

Yang L, Liu H, Wang Y, Zhu J and others (2009a) Yield formation of $\mathrm{CO}_{2}$-enriched inter-subspecific hybrid rice cultivar Liangyoupeijiu under fully open-air field condition in a warm sub-tropical climate. Agric Ecosyst Environ 129:193-200

Yang LX, Liu HJ, Wang YX, Zhu JG and others (2009b) Impact of elevated $\mathrm{CO}_{2}$ concentration on inter-subspecific hybrid rice cultivar Liangyoupeijiu under fully open-air field conditions. Field Crops Res 112:7-15

Submitted: December 19, 2011; Accepted: February 27, 2012 Proofs received from author(s): July 12, 2012 